\title{
Contemporary views on the lawfulness of naval blockades
}

\author{
Martin David Fink
}

Published online: 7 September 2011

(C) The Author(s) 2011. This article is published with open access at Springerlink.com

\begin{abstract}
The traditional law of blockade has several technical requirements that if not met renders a blockade unlawful. These traditional requirements balance the interests of the belligerent and neutrals. A more contemporary view on the law of blockade, however, emphasizes that blockades are also subject to the restrictions and general obligations imposed by treaties and general principles of humanitarian law. Crucially, whether or not the consequences of a breach of humanitarian principles or humanitarian law render a naval blockade unlawful or not is however not at all clear. The recent use of naval blockades during the Israeli military operations has given rise again to the discussion as to what renders a blockade unlawful. The maturation of the law of blockade has seen an increasing willingness to embrace aspects of humanitarian law. However, the diversity of views from the international community as endorsed by the published reports on the flotilla incident demonstrates that there remains a lack of consensus and an active discussion on the state of the law of blockade.
\end{abstract}

Keywords Law of blockade - Israel · Naval operations · Laws of naval warfare $\cdot$ Maritime interdiction operations

M.D. Fink is a lieutenant-commander in the Royal Netherlands Navy and is currently posted as assistant legal advisor at NATO Allied Joint Force Command Naples, Italy. The views expressed in this article are those of the author and do not represent those of the Royal Netherlands Navy, The Netherlands Government or NATO.

M. D. Fink

Royal Netherlands Navy, Den Helder, The Netherlands

Present Address:

M. D. Fink ( $ه)$

NATO Allied Joint Force Command, Naples, Italy

e-mail: finkmd@hotmail.com 


\section{Introduction}

On 31 May 2010, Israeli military personnel boarded the so called Freedom flotilla, a group of vessels bound for the Gaza, in international waters in order to prevent it from sailing into Gaza. The Israeli intervention resulted in nine passengers death with several more wounded. The Israeli government maintained that the maritime interdiction was legitimate because: 'A maritime blockade is in effect off the coast of Gaza. Such blockade has been imposed, as Israel is currently in a state of armed conflict with the Hamas regime that controls Gaza'. ${ }^{1}$ The disastrous consequences of the boarding instantly made the Freedom Flotilla incident world news with headlines such as: 'Israeli attacks sets storm of criticism', appearing on the front page of the International Herald Tribune, ${ }^{2}$ conveying a sense of outrage. Before, but also after the flotilla incident, other vessels bound for Gaza were intercepted and diverted based on the existence of a naval blockade but attracted less media attention. ${ }^{3}$ At the centre of the legal discussion within the media is the debate over the applicability of relevant law, whether the Israeli blockade is legally justifiable and the consequences that follow (Guilfoyle 2010; Vreeken 2010; Fink 2010; Dershowitz 2010). ${ }^{4}$ Without answering these questions, the President of the Security Council issued a statement a day after the incident in which he condemned the Israeli actions, called for an investigation and reiterated the UN's grave concerns on the humanitarian situation in the Gaza, already addressed in UNSC-resolutions 1850 (2008) and 1860 (2009). ${ }^{5}$ Interestingly, the Council's statement did not specifically comment on the legality of the blockade itself, and it only requested (as opposed to demanded) the immediate release of the persons detained by the Israeli during the operation. ${ }^{6}$ Some states, such as Turkey, ${ }^{7}$ declared the blockade to be illegal. ${ }^{8}$ Others, such as the Netherlands, only called for a lifting of the blockade, but without expressing an opinion on its legality. ${ }^{9}$

\footnotetext{
${ }^{1}$ http://www.mfa.gov.il/MFA/Government/Law/Legal+Issues+and+Rulings/Gaza_flotilla_maritime_ blockade_Gaza-Legal_background_31-May-2010.htm.

2 International Herald Tribune, 1 June 2010, p. 1 and 5.

${ }^{3}$ In February 2009 the Togo flagged vessel Tali was diverted which caused some stir. See: http://www.nytimes.com/2009/02/06/world/middleeast/06mideast.html. In September 2010 the Irene was diverted while sailing to the Gaza. See: http://idfspokesperson.com/2010/09/28/provocationyacht-on-its-way-to-ashdod-port-boarded-by-israel-navy-without-incident-28-sept-2010/.

${ }^{4}$ International Herald Tribune, 1 June 2010: 'Israeli attack sets off storm of Criticism', Page 1.

${ }^{5}$ S/PRST/2010/9, 1 June 2010.

${ }^{6}$ The statement on the detained persons reads:

'The Security Council requests the immediate release of the ships as well as the civilians held by Israel. The Council urges Israel to permit full consular access, to allow the countries concerned to retrieve their deceased and wounded immediately, and to ensure the delivery of humanitarian assistance from the convoy to its destination'.

${ }^{7}$ The persons that we killed on the board the Mavi Marmara all had Turkish citizenship. See table Hudson-Philips report, pp. 28-29.

${ }^{8}$ See SC/9940, 31 May 2010.

9 Press release of the Netherlands Ministry of Foreign Affairs 31 May 2010, 'Nederland wil opheldering Israël over geweld Gaza-schepen', at: http://www.minbuza.nl/nl/Actueel/Nieuwsberichten/2010/05/ Nederland_wil_opheldering_Israël_over_geweld_Gaza_schepen.
} 
The Israeli blockade of the Gaza-strip was originally established on 3 January 2009 as part of the ongoing operations against Hamas (Operation Cast Lead). ${ }^{10}$ The blockade was not lifted when military operations ceased but remained in force. It is not the first time that Israel has used a naval blockade in its recent military operations. During the second Lebanon War in the summer of 2006, Israel also established a blockade off the coast of Lebanon during Operation Change of Direction. Israel justified the action based upon the right of self-defense, after two Israeli soldiers were captured by Hezbollah (Schmitt 2008). The blockade off the coast of Lebanon started in July 2006 and ended in October of the same year, followed by an UN arms-embargo operation off the coast of Lebanon, enforced by a Maritime Taskforce of the UNIFIL peacekeeping mission, authorized by UNSCR 1701 (2006). Whilst both maritime operations were directed against the Hezbollah, they relied upon separate and distinct legal justifications. ${ }^{11}$

The Israeli belligerent blockade operations once again brought into the spotlight a rather obscure subject of international law: the law of blockade. As part of the law of naval warfare, the law of blockade and its concepts remain outdated. Ronzitti, in his prominent article 'The Crisis of the traditional law regulating international armed conflicts at sea and the need for its revision' (Ronzitti 1988; see also on the discussion of revision of the laws of naval warfare, Ashley Roach 2000, pp. 76-77) has urged for a complete revision of the laws of naval warfare, including the laws of blockade, which remains without contemporary codification.

Several reports have already been published on the Israeli conduct of blockades and there are others underway. Three were adopted by the Human Rights Council of the United Nations: The report on the second Lebanon War of $2006,{ }^{12}$ the report on the Israeli operation Cast Lead (the Goldstone report ${ }^{13}$ ) and the report concerning the Freedom Flotilla incident in 2010 (the Hudson-Philips report ${ }^{14}$ ). Two other reports are pending investigations of the flotilla incident. One of the investigations was commissioned by Israel a few weeks after the incident and presided over by Judge Jacob Turkel (Turkel Commission) with international observers (William David Trimble and Ken Watkin). ${ }^{15}$ The second consisted of a panel appointed by

\footnotetext{
${ }_{10}$ http://www.mag.idf.il/592-4071-en/patzar.aspx.

11 See on the UNIFIL maritime taskforce (Weingärtner 2007; Fink 2008).

$12 \mathrm{~A} / \mathrm{HRC} / 3 / 2,26$ November 2006. Report of the commission of inquiry on Lebanon pursuant to Human Rights Council resolution 2/1, 23 November http://www.island.1k/2009/02/07/world5.html 2006 (A/HRC/ 15/21). Available at: http://www.unhcr.org/refworld/country,,UNHRC,,LBN,4562d8cf2,45c30b6e0,0. html.
}

13 A/HRC/12/48, 25 September 2009. Report of the United Nations Fact-Finding Mission on the Gaza Conflict. Available at: http://www2.ohchr.org/english/bodies/hrcouncil/specialsession/9/factfindingmission.htm.

14 A/HRC/15/21, Report of the international fact-finding mission to investigate violations of international law, including international humanitarian and human rights law, resulting from the Israeli attacks on the flotilla of ships carrying humanitarian assistance (27 September 2010), available at: http://ap.ohchr.org/documents/alldocs.aspx?doc_id=17700.

15 At: http://www.mfa.gov.il/MFA/Government/Law/Legal+Issues+and+Rulings/Independent_Public_ Commission_Maritime_Incident_31-May-2010.htm?WBCMODE=Pr?DisplayMode=print. The website of this commission as at: http://www.turkel-committee.com/index-eng.html. Israel first rejected an international commission to inquire on the raid and later decided to have an Israeli commission with international observers (Kershner 2010). 
the UN-Secretary-General Ban Ki-moon and led by Geoffrey Palmer. ${ }^{16}$ While the penal led by Palmer has yet to report its findings, ${ }^{17}$ a first part of the report by the Turkel Commission has already been released on 23 January $2011,{ }^{18}$ and discusses, amongst others, the question: 'Whether the actions carried out by Israel to enforce the naval blockade on May 31, 2010, complied with the rules of international law'. ${ }^{19}$ The Hudson-Philips and the Lebanon report consider the method of blockade as part of the overall Israeli military operations. All three reports therefore offer an interesting perspective on the contemporary view of the application of the law of naval blockade. What makes it even more interesting is that the Hudson-Philips Mission and the Turkel Commission reach different conclusions on the naval blockade. The latter concludes that the blockade is in compliance with international law, whereas the Hudson-Philips report argues that the blockade was unlawfully established. The Goldstone report, whilst it analyses the closure of Gaza as a whole, does not contain any specific analysis of the naval blockade or upon the law of blockades. $^{20}$

\subsection{Structure}

This article focuses on the contemporary development of the law of blockade seen against the backdrop of the recent practice of the Israeli military operations. The aim is to raise awareness of the state of the law of blockade and to argue for the adoption of a more modern approach in which the traditional balance between interests of neutrals and belligerent is considered in the context of international humanitarian law and principles. I will first make a few remarks on the legal requirements and principles of the traditional and modern law of blockade. Second, I will consider what renders a blockade unlawful when it does not meet the requirements under either the traditional or modern law of blockade. I do not propose to consider the question of the legality of the Israeli military actions on board the Mavi Marmara in this article or the question whether the laws of naval warfare or international humanitarian law as a whole are applicable to the situation in the Gaza (Guilfoyle 2011; Darcy and Reynolds 2010), which is beyond the scope of this article.

\section{The traditional law of blockade: technical requirements}

The legal debate that emerged from the freedom flotilla incident did not so much revolve around any treaty on the law of blockade, but around customary law,

\footnotetext{
16 http://www.un.org/apps//news/story.asp?NewsID=35584\&Cr=FLOTILLA\&Cr1=.

17 At 25 February 2010.

18 The report can be found at: http://www.mfa.gov.il/LegalAdvocacy/Delegitimization/GazaFlotilla/ Turkel-Commission-publishes-first-part-of-report-23-Jan-2011.htm.

19 See covering letter of the report.

${ }^{20}$ See on commentary on this report for instance (Blank 2009).
} 
national military commander's handbooks, ${ }^{21}$ and the San Remo Manual on international law applicable to armed conflicts at sea (Doswald-Beck 1995a) in particular. This is because, other than the Declaration of Paris (1856) ${ }^{22}$ concluded after the end of the Crimean War (1853-1856), no treaty exists that regulates the law of blockade. Its legal boundaries are mainly developed via state practice and domestic prize courts (Garner 1927a; Verzij1 1917). The Declaration of London of 1909 was intended to fill this gap in international law in the wake of setting up an international prize court. As the British foreign secretary Sir Edward Grey wrote to the nations invited to the London Conference, organized as a follow up to the second Hague Convention of 1907, 'The impression that was gained that the establishment of the International Prize Court would not meet with general acceptance so long as vagueness and uncertainty exists as to the principles which the Court (...) would apply to questions of far-reaching importance affecting naval policy and practice'. ${ }^{23}$ An International Prize Court would have needed a set of rules, including rules on blockade, which were internationally acceptable. The London Declaration suffered a similar fate to the Hague Convention XII on the International Prize Court; it was never ratified and lost its momentum in the years leading up to the First World War. The efforts devoted to the London Declaration on the law of blockade were not really wasted as most of the 21 articles in the Declaration that deal with blockade are considered as international customary law and are considered as having the status of legal guidelines when states apply the law of blockade (Green 2000).

\subsection{Notification, effectiveness and impartiality}

There are as many definitions of a blockade as there are legal handbooks that describe the subject. One can be found in the San Remo Manual (SRM): 'Blockade is the blocking of the approach to the enemy coast, or part of it, for the purpose of preventing the ingress and egress of vessels [or aircraft] of all states'. ${ }^{24}$ The traditional law of blockade requires three main elements to be satisfied for a blockade to be lawfully established. They are technical in nature and deal with the establishment of a blockade and with the manner in which a blockade must be conducted. The first requirement for establishing a blockade is that it must formally

\footnotetext{
${ }^{21}$ Much used as reference is the United States' Commander's Handbook on the law of naval operations that is seen as an authoritative handbook on maritime operational law (Thomas and Duncan 1999).

22 The fourth declaration of the Paris Declaration reads as follows:

Les blocus, pour être obligatoires, doivent être effectifs, c'est-a-dire maintenus par une force suffisante pour interdire réellement l'accès du littoral de l'ennemi.

23 Letter from 'Sir Edward Grey to his Majesty's Representatives at Berlin, Madrid, Paris, Rome, St. Petersburgh, Tokio, Vienna and Washington', in Correspondence and documents respecting the international naval conference, held in London December 1908-February 1909 (1909).

24 San Remo manual, p. 176. The Turkel-commission for instance chose to use the definition of the US Navy's Commander's Handbook on the law of naval operations (Thomas and Duncan 1999): 'Blockade is a belligerent operation to prevent vessels and/or aircraft of all nations, enemy as well as neutral, from entering or exiting specified ports, airfields, or coastal areas belonging to, occupied by, or under the control of an enemy nation'.
} 
be declared by the belligerent establishing it through several notifications. ${ }^{25}$ The purpose of the notifications is to inform all whom it may concern of its existence, details and its implications, in particular for neutral states and vessels. A diplomatic notification informs the neutral states and acts as a declaration, as Bentwich states: 'which is the act of the competent authority (the belligerent Government or its naval commander) stating that a blockade is or is about to be established' (Bentwich 1911). The London Declaration further requires that the commander of the blockading force must notify the local authorities concerned. ${ }^{26}$ Whether a captured vessel is supposed to know that its destination was barred by a blockade is a question for a prize court. However, with the existence of mass communication available also in the maritime dimension one would argue that it is hard to miss something as important as a blockaded coast or port. Indeed a notice to mariners intended to reach interested maritime parties is frequently used to distribute information on any kind of maritime zones, such as a blockade. Apart from informing neutral states through diplomatic channels, notification by means of a notice to mariners seems to be an accepted practice. ${ }^{27}$ Apart from these notifications some authors argue that commanders at sea should also warn every individual vessel that tries to run the blockade (van Bylandt 1880). This is not an obligation under the traditional law of blockade, but one could consider individual warnings in a graduated response towards enforcing measures.

The second requirement is that the blockade must be enforced in a manner which is both effective and impartial (Tucker 1955; Fraunces also adds the respect for neutral rights to the main principles, Fraunces 1992, p. 895). How one measures effectiveness has always been the subject of continuing debate that has evolved as military technology develops. ${ }^{28}$ Legally, there is no more guidance offered than the general phrase: 'whether it is effective is a question of fact', ${ }^{29}$ which stems from the

\footnotetext{
25 See articles 8, 9, 11, 16 LD.

26 Art. 11 sub 2 LD. Garner mentions a case during the Italian blockade in the Adriatic Sea against Albania during the First World War in which Italy notified the Greek Legation in Rome of the blockade but did not notify the local authorities. Despite that omission the Italian Prize Court put no consequence to it (Garner 1927, p 626). See also Verzijl (1917), pp. 189-190.

27 See para's 58-60 of the Turkel report for an analysis of the notification that was published by Israel on the Gaza blockade. The main concern of the commission is that it has no exact duration period as is a requirement under paragraph 94 SRM, but mentions that the blockade will be established "until further notice". It is however not a requirement under the London Declaration. The passage according to the Commission does not affect the legality of the notification. The notice to mariners reads as follows:

NO. 1/2009 Blockade of Gaza Strip, Tuesday, 06 January 2009 00:00

1. Subject: Blockade of Gaza Strip

2. Source : Israeli Navy
}

All mariners are advised that as of 03 January 2009, 1700 UTC, Gaza maritime area is closed to all maritime traffic and is under blockade imposed by Israeli Navy until further notice. Maritime Gaza area is enclosed by the following coordinates:

$3135.71 \mathrm{~N}, 3429.46 \mathrm{E} ; 3146.80 \mathrm{~N}, 34$ 10.01E; 31 19.39N, $3413.11 \mathrm{E} ; 3133.73 \mathrm{~N}, 3356.68 \mathrm{E}$

See for a map of the blockaded zone: C. Migdalovitz, Israel's Blockade of Gaza, the Mavi Marmara Incident, and Its Aftermath (Congressional Research Service, 23 June 2010), p. 16. Available at: http://www.crs.gov.

28 See for instance (Barnett 2005).

29 Art. 3 LD, 95 SRM. 
1856 Paris Declaration. ${ }^{30}$ The rule bans the so called paper-blockades that are declared but not enforced by military means. In operational terms, enforcing an effective blockade means assigning a sufficient force of often scarce assets to prevent the ingress and egress of a port or coast for a certain period of time. States may therefore have difficulty in establishing an effective blockade because they do not have enough naval assets available. Having said that, because of military operations are nowadays mostly conducted in a multinational role, a coalition could more realistically provide such an effective force.

The principle of impartiality requires that the blockade must be enforced against every vessel of every nation. Contrary to the law of contraband that allows only the capture of contraband goods, a blockade is all encompassing and does not allow any vessel to pass through it. In the classic case Franciska (1854), the English Privy Council also added that even merchant vessels belonging to the blockading party were not allowed to pass a blockade. ${ }^{31}$ Although some nations may be more affected than others by a blockade, impartiality, as Schmitt mentions, 'also protects neutral nations in the sense that selective enforcement of a blockade towards neutrals can be seen as a form of economic warfare against both the opponent and the victimized neutral' (Schmitt 1992, p. 38). Exceptions in the London Declaration to impartiality are made for vessels in distress and neutral warships. ${ }^{32}$ These exceptions are however expressed in terms of the belligerent party allowing certain activities, not as a positive right for the neutral. Tucker mentions that impartiality is not violated if the commander of a blockading force allows a neutral warship to pass the blockade and to depart from a blockaded port, however under the belligerents' conditions. ${ }^{33}$ Obviously the decision to allow or deny the passage of neutral warships through a blockade for instance to evacuate its subjects will be a sensitive political decision. As discussed below, the modern aspects of the law of blockade has added more exceptions to the principle of impartiality, but as a matter of obligation for the belligerent instead of a right. Although the SRM has not taken over the provisions concerning vessels in distress at sea, one could argue that the blockading party will also need to take into account the international law of the sea, in which there is a general obligation to render assistance to vessels in need. ${ }^{34}$

\footnotetext{
30 See note 22 above.

31 The Danish flagged merchant vessel Franciska was captured on 22 May 1854 in the Gulf of Riga which was at the time blockaded by Great Britain as part of military operations against Russia during the Crimean War. The Council stated in this case that: No blockade can be legitimate that admits to either belligerent a freedom of commerce denied to the subjects not engaged in the war (Moore 1855-1857, p. 48). See on the blockade operation (Lambert 2006).

32 Artt. 6 and 7 LD; 100 SRM.

33 Tucker (1955), 291. See also the explanations (p. 178) of the San Remo Manual on this point in paragraph 100: 'Although neutral warships and military aircraft enjoy no positive right of access to blockaded areas, the belligerent imposing the blockade may authorize their entry and exit'.

34 See article 98 UNCLOS III. See on the relationship between the international law of the sea and the laws of naval warfare chapter 17 (Military uses of the sea) of R.R. Churchill and A.V. Lowe, The law of the sea (1999). Tucker mentions that whether merchant vessels in evident distress may demand a permission to enter a blockaded port is unsettled. Tucker (1955), 291. Now more than 50 years later and against the background of a thorough development of the international law of the sea, it may still not be that the vessel in distress can demand permission but the obligation to render assistance is now a well established principle.
} 


\section{The modern law of blockade: balancing humanitarian principles}

In essence the traditional law of blockade seeks to achieve a balance between belligerent and neutral rights. The rule that a blockade may not bar access to neutral ports and coasts is a classic and specific example of this balance in force, ${ }^{35}$ as is the principle of impartiality and the duty to notify. Due to the use of exclusion zones during the Iraq-Iran war in the Persian Gulf (Boczek 1989, pp. 250-253) and the Falklands War and the use of maritime forces to enforce UN-embargoes from the 1990s onwards, the legal aspects of exclusion zones (Michaelsen 2003; Goldie 1991; Politakis 1998) and maritime embargo operations (Wynkoop 1995; Politakis 1994; Rosensweig 1995) have received much attention, often choosing the law of blockade as the legal point of departure for unchartered areas of law (Fielding 1993). The development of the law of belligerent blockade itself, however, fell away to the background, not in the least because there has hardly been any practical situation in which the law of blockade has been exercised. In the judgment of the ICTY against Pavle Strugar who conducted the military operations against the Dubrovnik region during the battle for Croatian independence in 1991, the Court does mention the use of a blockade by the Yugoslav People's Army against Dubrovnik. ${ }^{36}$ Whilst the development of humanitarian principles has gained much ground within the law of military operations, the law of blockade, specifically with regard to the relationship between the law of blockade, has not thoroughly matured. ${ }^{37}$

The traditional law of blockade does not contain any provisions that consider the wellbeing of civilians of a nation who are besieged from the sea. The development of humanitarian principles and law has, however, not left the law of blockade untouched. The law of blockade is subject to the restrictions imposed by the treaties and general principles of humanitarian law. Whereas the legality of the blockades during, for instance, the Korean War (1950) or the Indo-Pakistani conflict (1971) were discussed along traditional law requirements, ${ }^{38}$ only more recently during the embargo operations against Iraq in 1990 imposed by UNSCR 665 (1990) the importance of humanitarian principles and obligations became more of a focus in these kinds of naval operations. Although it must be emphasized that embargo operations are not the same as classical belligerent blockades in the strict legal

\footnotetext{
35 See art. 18 LD; 99 SRM.

36 See Prosecutor versus Pavle Strugar, trial judgment, IT-01-42-T, 31 January 2005, para's 31-39. Whether or not this blockade was established in accordance with the requirements of the law of blockade is unknown.

37 A more recent blockading activity that is often called "a naval blockade" has been the blockade that was established in 2007 by the African Union around one of the Comoros Islands (Anjouan) in support of the Union of Comoros Government, which preceded operation Open democracy in the Comoros. Of this Comorian conflict, that went unnoticed to most of the world, little information of the blockade operations seems available. Given the fact that the African Union supported in an internal matter, presumably, it may have been a blockade only in fact and name, but not in the sense of a belligerent blockade. See on this conflict Massey and Baker (2009).

38 See elaborately on these blockades G.P. Politakis (1998), pp. 62-69; Fielding (1993), pp. 1207-1211; (Baer 1993) (on Korea), pp. 320-324.
} 
sense, ${ }^{39}$ still we see here the emergence of the debate on the concept of economical closure of a State and the impact it has on the civilian population and the obligations under humanitarian law. ${ }^{40}$ The development of classical belligerent blockades in relation to humanitarian law was neglected until the establishment of the SRM which took up the task of modernizing the law of naval warfare and merged some aspects of humanitarian law with blockade law.

Today, the traditional balance between the belligerent and the neutral has changed into a more complex balance between the belligerent, the neutral, humanitarian principles and other areas of law that are intertwined with the use of a naval blockade. This renewed balance of interacting laws and principles is the basis upon which the modern approach to the law of blockade must now be seen. Although it is well understood that the belligerent imposing a blockade as a method of warfare also has obligations under the principles of international humanitarian law and other relevant international law which cannot be lawfully ignored, the manner in which these different aspects of the modern law of blockade should interact is not completely clear. Many questions on the application of the modern law of blockade and its consequences remain therefore unresolved. The modern approach to the law of blockade has until recently not enjoyed any practice or any case law to crystallize it, nor did this approach reach a level of formal codification.

Attempts to merge humanitarian principles with traditional blockade law have obviously led to debate. Some provisions of the laws of war that impose extra obligations for a belligerent during a blockade are easily incorporated in the enforcement of a blockade, such as obligations of letting relief actions pass. ${ }^{41}$ Others are more difficult and have resulted in calls from commentators to render parts of the law of blockade obsolete. By way of example, the all encompassing effect of a blockade to a nation's economy and its civilians is for instance difficult to reconcile with the humanitarian principle of distinction. This has led to the argument advocated by some academics that article 54 of the First Additional

\footnotetext{
39 Although art. 42 of the UN-Charter has the possibility to impose a blockade as measure, UNSCR 665 mentions that:

1. calls upon those Member-States co-operating with the Government of Iraq which are deploying maritime forces to the area to use such measures commensurate to the specific circumstances as may be necessary under the specific authority of the Security Council to hold all inward and outward maritime shipping, in order to inspect and verify their cargoes and destinations and to ensure strict implementation of the provisions related to such shipping laid down in resolution 661 (1990);
}

Apart from the discussion whether or not the laws of naval warfare should be applicable to this interdiction operation, in this case maritime shipping could actually pass the embargo if they comply to with the albeit strict provisions of UNSCR 661. As such it may resemble but is not a blockade in the traditional sense that encompasses that no shipping at all may pass the blockade. See discussion on the "blockade" against Iraq (Robertson 1991, pp. 10-13). Robertson mentions among other things that: unlike in blockade ships that attempted to deliver the prohibited items were turned back instead of being captured (p. 11).

40 Jones briefly mentions in 1983 as a last observation the obligations under the Geneva laws (Jones 1983). In 1992 Fraunces still does not mention any of the humanitarian aspects while proposing new guiding principles in the law of blockade. Fraunces (1992), pp. 893-918.

41 Art. 70 API. 
Protocol to the Geneva Conventions (API) concerning the prohibition to starve the civilian population prohibits blockades as a lawful method of combat as a whole. In 1990 Van Hegelsom wrote that this argument is not generally accepted (van Hegelsom 1992, p. 46). Proponents of this view ${ }^{42}$ see their argument supported by article 49, paragraph 3 API that reads:

(3.) The provisions of this section apply to any land, air or sea warfare which may affect the civilian population, individual civilians or civilian objects on land. They further apply to all attacks from the sea or from the air against objectives on land but do not otherwise affect the rules of international law applicable in armed conflict at sea or in the air.

For some States, merging the law of blockade with the provisions of API could be one step too far particularly if they are not a party to additional protocols, as is the case of the United States and Israel. The US-commander's handbook on naval operations for instance only goes so far as to mention the traditional requirements and does not consider the modern humanitarian aspects as obligations under the law of blockade (Thomas and Duncan 1999, pp. 390-395). In this situation the legal obligation of non-signatories of the Protocol under these rules may depend on whether or not the specific provision is already viewed as customary international law.

\subsection{The San Remo Manual}

The SRM is the result of a "seven year project on the 'modernization' of the law of armed conflict at sea", as the editor Doswald-Beck of the Manual has described it (Doswald-Beck 1995b, p. 192). It is widely considered as the most modern and authoritative publication concerning the laws of naval warfare. The SRM sought to modernize the laws of naval warfare, keeping in mind that developing technology, humanitarian law and international law of the sea all have had its impact on the applicability of the laws of naval warfare in contemporary naval operations. The SRM has a specific section that deals with the rules on blockades. They can be divided in paragraphs which basically restate the customary international law on blockades (par. 98-101 SRM) on the one hand and paragraphs that are an effort to update the laws of naval warfare with humanitarian principles (par. 102-104) on the other. These latter sections read as follows:

102. The declaration or establishment of a blockade is prohibited if:

(a) it has the sole purpose of starving the civilian population or denying it other objects essential for its survival; or

(b) the damage to the civilian population is, or may be expected to be, excessive in relation to the concrete and direct military advantage anticipated from the blockade.

103. If the civilian population of the blockaded territory is inadequately provided with food and other objects essential for its survival, the blockading

$\overline{42}$ Like Dinstein (see Dinstein 2004). 
party must provide for free passage of such foodstuffs and other essential supplies, subject to:

(a) the right to prescribe the technical arrangements, including search, under which such passage is permitted; and

(b) the condition that the distribution of such supplies shall be made under the local supervision of a Protecting Power or a humanitarian organization which offers guarantees of impartiality, such as the International Committee of the Red Cross.

104. The blockading belligerent shall allow the passage of medical supplies for the civilian population or for the wounded and sick members of armed forces, subject to the right to prescribe technical arrangements, including search, under which such passage is permitted.

These sections are an attempt to merge articles 54 sub $1,{ }^{43} 70^{44}$ API and the principle of proportionality with the law of blockade. According to the international customary law study of the ICRC, the content of both articles of the Geneva Conventions can also be seen as customary law. ${ }^{45}$ Thus the provisions are applicable whether or not a state is a party to API. The second section on blockades referred to in the SRM is often quoted as constituting essential guidelines or sometimes even quoted as law. Not surprisingly, it is also the centre-piece of the legal discussion in the freedom flotilla incident and used as a basis for the different investigators. The Hudson-Philips report mentions that: 'While not authoritative, its

43 Art. 54 sub 1 API (protection of objects indispensable to the survival of the civilian population) reads as follows:

1. Starvation of civilians as a method of warfare is prohibited.

44 Art 70 API (relief actions) reads as follows:

1. If the civilian population of any territory under the control of a Party to the conflict, other than occupied territory, is not adequately provided with the supplies mentioned in Article 69, relief actions which are humanitarian and impartial in character and conducted without any adverse distinction shall be undertaken, subject to the agreement of the Parties concerned in such relief actions. Offers of such relief shall not be regarded as interference in the armed conflict or as unfriendly acts. In the distribution of relief consignments, priority shall be given to those persons, such as children, expectant mothers, maternity cases and nursing mothers, who, under the Fourth Convention or under this Protocol, are to be accorded privileged treatment or special protection.

2. The Parties to the conflict and each High Contracting Party shall allow and facilitate rapid and unimpeded passage of all relief consignments, equipment and personnel provided in accordance with this Section, even if such assistance is destined for the civilian population of the adverse Party.

3. The Parties to the conflict and each High Contracting Party which allow the passage of relief consignments, equipment and personnel in accordance with paragraph 2:

(a) shall have the right to prescribe the technical arrangements, including search, under which such passage is permitted;

(b) may make such permission conditional on the distribution of this assistance being made under the local supervision of a Protecting Power;

(c) shall, in no way whatsoever, divert relief consignments from the purpose for which they are intended nor delay their forwarding, except in cases of urgent necessity in the interest of the civilian population concerned.

4. The Parties to the conflict shall protect relief consignments and facilitate their rapid distribution.

5. The Parties to the conflict and each High Contracting Party concerned shall encourage and facilitate effective international co-ordination of the relief actions referred to in paragraph 1 .

45 See rule 53 of the ICRC-customary study. 
codification effort has had a significant impact on the formulation of military manuals and it has been expressly relied upon by Israel'. ${ }^{46}$ The Turkel-commission comments upon the SRM: 'This manual will serve as the primary basis for the legal analysis of the issues before the Commission. However, since some of the provisions in the SRM are regarded as reflecting a progressive development of the law rather than merely a restatement thereof, the analysis below is also based on other accepted texts and manuals in order to identify areas where there may not be complete international consensus on the San Remo rules'. ${ }^{47}$ The Turkel-commission also touches upon an opposing view concerning the legal applicability of these rules. It comments that the rules in general may be seen as customary law; the document itself does not bind states as a treaty would. Even if both the humanitarian law and blockade law independently can be considered as customary law, the merged customary status of paragraphs 102-104 SRM is still open to debate. There may be opinio iuris, but without actual practice the question as to whether these sections should be granted the status of customary international law is still a question that remains subject to debate. ${ }^{48} \mathrm{Up}$ until the recent Israeli blockades there has been no opportunity to test these particular sections. The economic sanctions imposed by the UN-Security Council against Iraq that prevented trade from entering Iraq in 1990 reignited the debate on blockade-type of naval operations and the responsibilities under the Geneva Conventions, but the effect of the sanctions legally did not constitute a belligerent blockade (Provost 1992; Sklaire 1990-1991; Geiss 2005).

\section{The Israeli blockades}

The importance of the debate on the contemporary scope of the international law of blockade is again underlined by the recent use of blockade operations by Israel. The reactions to the enforcement of the Gaza blockade by Israel suggest that the law of blockade with its far reaching implications ${ }^{49}$ seems to have been forgotten and does not sit comfortably with the contemporary view of legal use of the sea. ${ }^{50}$ Maritime principles, such as freedom of navigation and sovereignty of the flag state over a

\footnotetext{
${ }^{46}$ Hudson-Philips report, para. 50.

47 Turkel report, para. 33.

48 See also the discussion in general about state practice and the San Remo Manual in Dalton (2006).

49 Vessels that breach a blockade run the risk of being captured and confiscated. Its cargo may be condemned and its crew can be detained for the period the prize court will need to adjudicate the prize (Colombos 1962). See also article 20 and 21 LD; Tucker (1955), 295. Paragraph 98 SRM mentions that: 'Merchant vessels believed on reasonable grounds to be breaching a blockade may be captured. Merchant vessels which, after prior warning, clearly resist capture may be attacked'. See also paragraph 146f and 67 SRM. The Hudson-Philips report—after having concluded that the blockade was illegal-argues that: 'there was no legal basis for the Israeli authorities to have detained and transported these people to Israel. The passengers found themselves in Israel on the basis of an unlawful act by the State of Israel'. See para's. 183-233, in particular para. 215.

50 What falls outside of the scope of the topics discussed in this article is the question how to enforce a blockade relates to the freedom of the high seas. Immediately after the flotilla incident the argument was often used that the unlawfulness of the action flows from the fact that the convoy was sailing in international waters, which limits the legal possibilities to visit a vessel. See for instance: http://www.globalsecurity.org/military/world/war/operation-sea-breeze-legal.htm.
} 
vessel, appear to have taken precedence over the principles that are derived from the laws of naval warfare. Further, the Gaza blockade re-opened the discussion on what the modern requirements are to legally enforce a naval blockade. The flotilla incident is interesting in respect of the development of the law of blockade because both the traditional and the modern legal views are being adopted by the parties. As I will demonstrate in more detail below, the Hudson-Philips report sees the legality of the law of blockade primarily from the perspective of the humanitarian law aspects of enforcing a blockade and argues that breaches of humanitarian law can render a blockade unlawful. Israel and the Turkel Commission on the other hand take a more traditional approach and center their arguments on the traditional law.

\subsection{Human Rights Council reports}

Both the Lebanon report on the military operations against the Hezbollah and the Hudson-Philips report on the flotilla incident do not explicitly consider the traditional laws of blockade to be obsolete. In its analysis, the Hudson-Philips Mission refers to the traditional criteria, but only briefly. ${ }^{51}$ No in-depth analysis is made in respect of the principles of effectiveness, impartiality, notification or any other more detailed rule of the law of blockade. It also does not state whether in its view Israel has complied with these requirements or not. Greater attention is paid to the humanitarian aspects as mentioned in the SRM and the obligations of a belligerent under humanitarian law. ${ }^{52}$

The Lebanon report, whilst mentioning that the full scope of the law of armed conflict applies, ${ }^{53}$ does not refer to the traditional requirements of the laws of blockade. It does, however, discuss the impact of the blockade from a humanitarian, economical and environmental perspective. ${ }^{54}$ In paragraph $184-187^{55}$ of the report the Commission mentions the obligation to allow humanitarian relief to enter Lebanon but only late in the conflict, due to the delayed required authorization from the Israeli's. The Commission furthermore concluded that: 'Israel's engagement in an armed conflict does not exempt it from its general obligation to protect the environment and to react to an environmental catastrophe such as that which took place on the Lebanese coasts'. ${ }^{56}$ The report ultimately concludes in paragraph 275 that the blockade is disproportionate:

\footnotetext{
51 Hudson-Philips report, para. 51 .

52 Hudson-Philips report, para. 51.

53 On page 79 the Lebanon report mentions that:

Israel attacked Hezbollah as well as Lebanese targets, with the Lebanese armed forces barely putting up any resistance. This situation has been deemed a unique (sui generis) situation, whereby the comparison with the hostile occupation without resistance forces itself upon us. That approach leads to the full regime for international armed conflicts being applicable. This regime primarily consists of the Geneva Conventions, the First Additional Protocol applying to Israel insofar as the stipulations are of a customary law character. See also on the applicability of the law of armed conflict (Ducheine and Pouw 2009).

54 Lebanon report, para's 271-274.

55 See also para. 272 of the Lebanon report.

56 Lebanon report, para. 273.
} 
The Commission believes that the impact of the blockade on human life, on the environment and on the Lebanese economy seems to outweigh any military advantage Israel wished to obtain through this action. The Commission finds that the blockade should have been adapted to the situation on the ground, instead of being carried out in a comprehensive and inflexible manner that resulted in great suffering to the civilian population, damage to the environment, and substantial economic loss.

Interestingly, rather than concluding that as a result the blockade must be considered illegal or a prohibited method of combat, the Lebanon report states that the blockade should have been adapted so as to minimize the negative results. Clearly, from the perspective of the Human Rights Council rapporteurs, both reports view whether or not Israel adhered to the traditional laws in both blockade operations not to have a huge part in the legal debate. The view of the commissions is, however, not surprising given the steady development of the law of military operations in which humanitarian principles play an increasingly prominent role.

\subsection{Israel's view on the Gaza blockade}

The view from the UN-rapporteurs, not totally surprisingly, differs from that of the blockading belligerent itself. Israel's official legal statement bases the lawfulness of the Gaza blockade primarily on the traditional law perspective. ${ }^{57}$ It underlines the requirement of notification, impartiality and also repeats that it may not bar the access of neutral ports and coasts. Israel points out that it has fulfilled the requirements of the traditional law of blockade and understands that the consequences of breaching a blockade are that: "Any vessel that violates or attempts to violate a maritime blockade may be captured or even attacked under international law'.58

This statement does not mention the humanitarian obligations that arise from humanitarian law being part of the legal considerations of the lawfulness of a blockade. In another publication of the Israeli Ministry of Foreign Affairs concerning the legal aspects of the naval blockade, mention is made of the SRM as a justification for the legal conditions of the blockade. Apart from the traditional requirements mention is made of an obligation to allow the passage of humanitarian assistance, as mentioned in section 103 SRM. $^{59}$ Israel does not ignore the humanitarian aspects, but it does not consider it something that can affect the lawfulness of the blockade. It furthermore stops short of considering any other obligation under general humanitarian law. It appears therefore that Israel's view as to whether or not a blockade is lawfully established is seen separate from the obligations it perceives it has under humanitarian law.

Whereas the Hudson-Philips report is of the view that legal obligations outside the law of blockade can have an effect on the legality of establishing a blockade, the

\footnotetext{
57 See legal statement on the Gaza blockade: http://www.mfa.gov.i1/MFA/Government/Law/Legal+ Issues+and+Rulings/Gaza_flotilla_maritime_blockade_Gaza-Legal_background_31-May-2010.htm.

58 Para. 8 of the statement.

59 http://www.mag.idf.il/592-4071-en/patzar.aspx.
} 
Turkel Commission, as I will outline below, takes to the Israeli approach, staying close to the traditional law and its few already accepted intertwinements of humanitarian law. This is an important difference, also with regard to the legal consequences for an established blockade, which I will elaborate on in the next paragraphs.

\section{What renders a blockade unlawful?}

Legal literature on traditional blockade law is abundant on the requirements of how to establish a blockade and what the consequences for a vessel are when it is in violation. $^{60}$ It also emphasizes that when the requirements for establishing a blockade are not met, it is considered to be non-binding upon neutral Sates. In this situation, a belligerent state cannot make any use of the authorities based on the law of blockade. What exactly would render a blockade unlawful is, however, a more complex issue, especially when seen from the perspective of the modern law of blockade. In the following paragraphs I will consider three possible ways in which a blockade could be determined to be unlawful: Unlawfulness under traditional law, via a breach of humanitarian law and via a breach of the principles of the laws of war.

\subsection{Traditional law}

At first sight the traditional law seems quite clear on when a blockade is considered to be unlawful. If one of the requirements of notification or effectiveness is not met, a blockade can be considered non-binding upon neutral states. ${ }^{61}$ The technical requirement of notification is rather straight forward and easy to determine. But the debate obviously lies in the vagueness of the term 'effective'. As Heinegg mentions, 'there are no criteria that would make possible an abstract determination of the effectiveness of all blockades' (Heintschel von Heinegg 2006). Considering a blockade non-binding based on this requirement seems therefore difficult to establish and without an international court decision it would be hard to impose such a position on the blockading belligerent. Smith recalls a historical case in 1861 when the whole coast of the Confederate States of some 3,000 miles was blockaded by 45 ships and around 50 armed merchantmen of the United States. Although it was clear that the blockade was not effective, no neutral power contested it and the United States Supreme Court judged the blockade to be effective (Smith 1950). According to Verzijl there were ten "regular" blockades 62 established during the First World War against which no claims of ineffectiveness were ever raised. ${ }^{63}$

Although the London Declaration does not explicitly attach consequence to the non-fulfillment of the principle of impartiality, ${ }^{64}$ different authors referring to national

\footnotetext{
60 See for instance Tucker (1955), pp. 292-295.

61 Artt. 2 and 8 LD.

62 As opposed to the war zones or Sperrgebied that were used by the belligerents, which Verzijl calls irregular blockades and departed from the classical way of imposing a blockade. Verzij1 (1917), 197-223.

63 Verzijl (1917), 186-189.

64 Art. 5 LD.
} 
prize courts ${ }^{65}$ and military manuals regard impartiality as a condition. ${ }^{66}$ Section 100 $\mathrm{SRM}^{67}$ reiterates the rule of article 5 of the London Declaration on impartially, but it fails to mention whether or not it renders a blockade unlawful. A neutral state against who the principle is not adhered to will have the ability to complain to the belligerent. Such a complaint, however, gives rise to another issue, as a claim of a State that is of the opinion that the blockade is unlawfully established will not render the blockade automatically unlawful for the complaining State or any other neutral state. The mere claim may be legally correct and politically and internationally widely supported, but does not overrule a decision of another State. What is required is the determination of the issue by an independent body whose decision is binding upon all of the parties. This is further enshrined in the principle of impartiality.

Verzijl opines also that a breach of article 1 of the London Declaration ${ }^{68}$ will render a blockade unlawful because it lies in the very nature of the term 'blockade' that it is established against an enemy. ${ }^{69}$ Blockades established against States that cannot be considered as such must be considered as unlawful. He furthermore argues that the difference with article 18 of the London Declaration, which states that blockading forces must not bar the access to neutral ports or coasts, is that the blockade in the latter situation is not purposely directed against the neutral state but by its enforcement factually also closes a neutral port or coast. Although it is a breach of a provision of the law of blockade, it does not render the blockade itself null and void as a whole.

\subsection{Unlawfulness of a blockade via a breach of humanitarian law}

Using a blockade as a method of warfare runs the risk of breaching humanitarian law. The naval blockade can be the sole cause or aggravate the circumstances of the breach. It could, for instance, result in there being a shortage of food, medical and other essential supplies, that, if the conditions mentioned in for instance $23 \mathrm{GC} \mathrm{IV}$, $59 \mathrm{GC}$ IV or $70 \mathrm{API}^{70}$ are not met and/or no sufficient relief to the civilian population is given, may render the blockading party in breach of these articles. Seen from a modern law of blockade perspective that includes humanitarian law as

\footnotetext{
${ }^{65}$ See for instance the Franciska case, note 31 above.

${ }^{66}$ For instance the US commander's handbook (Thomas and Duncan 1999), para. 7.7.2.4. This paragraph reads:

A blockade must be applied impartially to the vessels and aircraft of all nations. Discrimination by the blockading belligerent in favor of or against the vessels and aircraft of particular nations, including those of its own or those of an allied nation, renders the blockade legally invalid.

${ }^{67}$ Section 100 SRM reads:

A blockade must be applied impartially to the vessels of all States.

${ }^{68}$ Art. 1 LD reads:

A blockade must not extend beyond the ports and coasts belonging to or occupied by the enemy.

69 Verzijl (1917), pp 190-191.

${ }^{70}$ The main difference between articles 23 and 59 GC IV is the fact that article 59 is an obligation for an occupying power whereas article 23 is not. The limit of article 23 however is, is that there are several conditions with regard to the foodstuff and other essentials in which not the whole civilian population in general falls under this provision. Art 70 API does mention civilian population in general but limit this right as it is under the conditions of the blockading party.
} 
a factor when considering the unlawfulness of a blockade, the question arises as to whether or not a breach of humanitarian law will also render the blockade unlawful.

There are no provisions within Geneva law that explicitly render a blockade unlawful if it is breached. But, as said above, legal literature usually does make a link between article 54 API that forbids starvation as a method of warfare and blockades (Heintschel von Heinegg 1992). In this respect the ICRC-commentary on article 54 API seems to differentiate between the intention and the result of the blockade. If starvation is the purpose of establishing the blockade, it breaches article 54 API. When a blockade has starvation as a result it triggers relief actions or could even lead to the evacuation of such persons, under article 17 GC IV (Sandoz et al. 1987). The ICRC-commentary does not, however, conclude that in this situation the blockade becomes unlawfully established, but it merely mentions the uncertain present state of the laws of naval warfare.

The same view with regard to the link between starvation and blockade is adopted by the SRM. The SRM also explicitly notes the consequences for an established blockade. Paragraph 102 SRM states that the establishment of a blockade for the sole purpose of starving the civilian population is prohibited. In line with the ICRC commentary this paragraph deals with the intention of the blockade and not with its consequences, or as the SRM-explanation says, its sideeffects $^{71}$ : 'Whenever the blockade has starvation as one of its effect, the starvation effectively triggers the obligation, subject to certain limitations, to allow relief shipping to gain access to the coasts of the blockaded belligerent'. ${ }^{72}$ This view is reflected in paragraph 103 and 104 SRM that is concerned with the results of the blockade and creates a duty to relieve the population of a blockaded area. A more practical argument as to why this situation would not render the blockade unlawful is that the choice of measures that are open to a belligerent to resolve the situation aside from lifting the blockade are numerous. If a belligerent can take measures that would address the violation while still enforcing the blockade, one can argue that it remains lawfully established. If it is for instance possible to allow the ingress of essential foodstuff by air and land to sufficiently address the deteriorating humanitarian situation, or alter the enforcement of the blockade with regards to allowing certain goods in, there is no ground to consider the naval blockade unlawful. ${ }^{73}$ The SRM's view towards potential unlawfulness of a blockade when its purpose is starvation is supplemented by the ICRC study on customary international humanitarian law (2005) which considers that the principle has the status of customary law (Henckaerts and Doswald-Beck 2005). It points out that siege warfare is forbidden if the purpose is to starve a civilian population, but not prohibited if the purpose is to achieve a military objective. It also specifically emphasizes that this principle also applies in the use of naval blockades and embargoes. In summary, breaches of particular provisions of humanitarian law with

\footnotetext{
71 Para. 102(2) SRM.

72 San Remo Manual, p. 179.

73 Also Israel decided after the incident to liberalize the system by which civilian goods enter Gaza and expand the inflow of materials for civilian projects under international supervision. See: http://www.mfa.gov.il/MFA/Government/Communiques/2010/Security_Cabinet_decision_17-Jun2010.htm.
} 
regard to the civilian population caused by a blockade create an obligation for the belligerent to take action to remedy the situation, but do not necessarily render the blockade unlawful, unless its purpose is to starve the blockaded population. As such, it appears that in principle it is accepted that a breach of humanitarian law can have an effect on the lawfulness of a blockade. In this respect it is interesting to mention the conclusions of the Hudson-Philips report and the Turkel-Commission.

\subsubsection{Collective punishment: the Hudson Philips-report}

The Hudson-Philips report takes a step further with regard to the already accepted norms for unlawfulness of a naval blockade. The Hudson-Philips Mission first of all draws the conclusion that the humanitarian situation in the Gaza is such that the laws of war are breached. The Mission classifies Israel's closure of Gaza that resulted in the grave humanitarian situation as collective punishment of the civilian population, which is prohibited according to article $33 \mathrm{GC} \mathrm{IV.}{ }^{74}$ This article states that:

No protected person may be punished for an offence he or she has not personally committed. Collective penalties and likewise all measures of intimidation or of terrorism are prohibited.

Pillage is prohibited.

Reprisals against protected persons and their property are prohibited.

Although Israel argues that the purpose of establishing the blockade lies in reasons of security, ${ }^{75}$ paragraph 54 of the report rejects this argument and mentions that: 'The Mission considers that one of the principal motives behind the imposition of the blockade was a desire to punish the people of the Gaza Strip for having elected Hamas. The combination of this motive and the effect of the restrictions on the Gaza Strip leave no doubt that Israel's actions and policies amount to collective punishment as defined by international law'.

A similar statement that article 33 GCIV is breached in the Gaza situation was made earlier by the ICRC. The ICRC condemned the closure of Gaza in a statement as a war crime: 'The whole of Gaza's civilian population is being punished for acts for which they bear no responsibility. The closure therefore constitutes a collective punishment imposed in clear violation of Israel's obligations under international humanitarian law'. ${ }^{76}$ In this statement the ICRC does however not specifically refer to the naval blockade that was established in 2009, but refers to the closure of Gaza as a whole that 'is about to enter its fourth year'. The report then goes on to conclude that the naval blockade was established in support of the overall closure regime that must be regarded as disproportionate, and thus also becomes illegally established. In addition to the view that the blockade is a disproportionate measure,

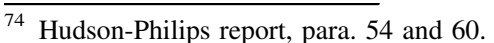

75 Hudson-Philips report, para. 33.

76 ICRC news release 10/103, 14-06-2010. 'Gaza closure: not another year!' Available at: http://www.icrc.org/web/eng/siteeng0.nsf/html/palestine-update-140610.
} 
it adds that the closure regime, of which the naval blockade is part, constituted collective punishment for the civilian population:

60. Furthermore, the closure regime is considered by the Mission to constitute collective punishment of the people living in the Gaza Strip and thus to be illegal and contrary to article 33 of the Fourth Geneva Convention.

Apart from judging the naval blockade through the principle of proportionality, the Mission appears to have also created a new ground to render a blockade unlawful by referring to article 33 GC IV: when a naval blockade is part of the breach of article 33 GC IV the blockade must be seen as unlawfully established. Finally, the Mission concludes that as a consequence of the unlawfulness of the blockade the military actions against the Mavi Marmara were therefore also unlawful:

261. The Mission considers that the enforcement of an illegal blockade does not only constitute a violation of the laws of war, but also a violation of the laws of neutrality giving rise to State responsibility.

262. Certain results flow from this conclusion. Principally, the action of the Israel Defense Force in intercepting the Mavi Marmara on the high seas in the circumstances and for the reasons given was clearly unlawful. Specifically, the action cannot be justified in the circumstances even under Article 51 of the Charter of the United Nations.

\subsubsection{The Turkel-Commission}

The Turkel-commission is very detailed on the issue of naval blockade. In its findings the commission is supported by two 'special consultants'; Wolff Heintschel von Heinegg and Michael Schmitt. In paragraphs 56-97 the issue of the naval blockade and its compliance with the law of blockade is discussed. Clearly the Commission takes the traditional law requirements as its central point of departure. It also considers humanitarian aspects to the law of naval blockade, but only as far as the provisions that are already considered as being a part of the modern law of blockade and mentioned in the SRM. Although it briefly considers the application of human rights, it is however reluctant to view the law of blockade from a wholly humanitarian perspective that reflects the complete scope of humanitarian law.

Contrary to the Hudson-Philips report the Turkel report pays more in-depth attention to the requirements under traditional blockade law. It discusses first its compliance with the traditional law of blockade and secondly discusses the modern humanitarian aspects of the law of blockade. With regard to the traditional law the overall conclusion is that Israel complied with the requirements of effectiveness, impartiality and notification. ${ }^{77}$ The report also gives an interesting insight into what action Israel has taken to fulfill the requirement of notification.

With regard to the modern (humanitarian) aspects of the law of blockade the report is guided by sections 102-104 SRM: 'Once a blockade is established, it is

\footnotetext{
77 Turkel report, para's. 57-60.
} 
likely to have a humanitarian impact on the civilian population in the blockaded area. The blockading party must therefore consider the humanitarian impact that the blockade will have on the civilian population of the territory'. ${ }^{78}$ Also on the humanitarian aspects the report concludes, similar to the their analysis on the issue of relief actions, ${ }^{79}$ that the steps taken by Israel during the naval blockade are 'consistent with customary international law as provided in articles 102(a) and 103 of the San Remo Manual'. 80

Because the Turkel report was published later than the Hudson-Philips report, it had the opportunity to comment on the views expressed by the Hudson-Philips Mission, specifically on the view of collective punishment, which is the main argument in the Hudson-Philips report against their being a lawfully established blockade. In paragraph 107 the Turkel Commission reaches the following conclusion with regard to collective punishment and the law of blockade:

107. As for the naval blockade itself, within the framework of the rules that govern the imposition and enforcement of such a blockade, there is no basis for an allegation of 'collective punishment.' There is nothing in the Red Cross' Customary International Law Study that in any way connects the idea of 'collective punishment' with a naval blockade or siege warfare On the contrary, the Study states that 'the prohibition of starvation as a method of warfare does not prohibit the imposition of a naval blockade as long as the purpose is to achieve a military objective and not to starve a civilian population. $^{81}$

The Turkel-Commission, contrary to Hudson-Philips, thereby takes a more restrictive view of the rendering a blockade unlawful through provisions of humanitarian law and is apparently of the opinion that the current law of blockade is limited to the already accepted intertwinements of humanitarian law with the law of blockade that are mentioned in the SRM. The Commission considered that other provisions of humanitarian law do not affect the legality of a blockade. A breach of article 33 GCIV is said to be outside of this scope and cannot therefore lead to the determination of a naval blockade being unlawful.

\subsection{Unlawfulness via a breach of the principles of the law of armed conflict}

Doswald-Beck mentions, while discussing the development of international law in the maritime dimension and the need for a revision of the traditional laws of naval warfare, that: 'Furthermore, all aspects of armed conflict should be in conformity with the basic principles of international humanitarian law, wherever the theatre of operations might be' (Doswald-Beck 1995c, p. 585). Although strictly not necessary, the SRM has incorporated the principle of proportionality into the law of blockade in section 102b. If the blockade cannot be considered proportional in

\footnotetext{
78 Turkel report, para. 61 .

79 Turkel report, para. 86 .

${ }^{80}$ Turkel report, para. 77.

81 Turkel report, para. 107.
} 
relation to the concrete and direct military advantage anticipated from the blockade, its establishment is prohibited. The Turkel Commission takes note of the disputed customary status of this rule by the Israeli Military Advocate General, ${ }^{82}$ but argues that even without a specific rule the principle of proportionality remains a principle that must be taken into account. The arguable difference would be that whether or not a blockade would become illegal is less explicit, but even if all the requirements of the (traditional) law are adhered to it still renders the blockade unlawful when the blockade is excessive in relation to the military advantage anticipated from the blockade. In the flotilla incident case both the view that the blockade was proportionate and disproportionate are taken.

The Hudson-Philips report stated that proportionality is a requirement for a legally established blockade. In paragraph 53 the Mission mentions that: 'In evaluating the evidence submitted to the Mission .......... confirming the severe humanitarian situation in Gaza, the destruction of the economy and the prevention of reconstruction (as detailed above), the Mission is satisfied that the blockade was inflicting disproportionate damage upon the civilian population in the Gaza strip and that as such the interception could not be justified and therefore has to be considered illegal'. As a conclusion the Mission underlines that:

59. The Mission finds that the policy of blockade or closure regime, including the naval blockade imposed by Israel on Gaza was inflicting disproportionate civilian damage. The Mission considers that the naval blockade was implemented in support of the overall closure regime. As such it was part of a single disproportionate measure of armed conflict and as such cannot itself be found proportionate.

With regard to the question of proportionality the Turkel report seeks to underline several factors that need to be taken into account when assessing proportionality. As a start the commission underlines the obligation not to cause excessive damage. ${ }^{83}$ With regard to military advantage, the commission is persuaded that if not for the blockade, Hamas could have replenished its weapons and increased its attacks on Israel by the sea, but notably the attacks have significantly decreased. ${ }^{84}$ It furthermore finds it necessary for the proportionality debate to compare the blockade with the economic sanctions imposed against Iraq in 1990, to show that the civilian population inherently suffers during economic sanctions, that although caused debate but was not condemned. ${ }^{85}$ Finally, it underlines that Israel has put in place mechanisms on the land borders that intends to regulate goods entering the Gaza. ${ }^{86}$ In conclusion:

The Commission has therefore reached the conclusion that Israel is in compliance with the requirement of proportionality provided in international

\footnotetext{
82 Turkel report, para. 88 .

83 Turkel report, para. 87.

84 Turkel report, para. 89.

85 Turkel report, para's 92-93.

86 Turkel report, para. 94.
} 
humanitarian law, especially in view of the extensive steps that it took recently in order to restrict the effects of the naval blockade and the land crossings policy on the population of the Gaza Strip. ${ }^{87}$

\subsection{More grounds for unlawfulness of blockades based on humanitarian law?}

Until now the naval law discussion on the unlawfulness of a blockade via a breach of humanitarian law has concentrated on a few provisions of humanitarian law. Whether or not one accepts the arguments of the Turkel report or the HudsonPhilips report, the Hudson-Philips report does offer a new approach to the unlawfulness of blockades based on a provision of humanitarian law. One author writing on the Gaza conflict has already adopted the view that the Israeli blockade could result in there being a breach of provisions such as article 33 and 55 GCIV, but has not added as a conclusion that the blockade is therefore unlawful (Sterio 2010). Although the Hudson-Philips report does not solely base its conclusion on the breach of article 33 GCIV, it opens the way to the understanding that there may be other situations where provisions of humanitarian law actually will impact on the legality of a naval blockade. This however may represent the next step in the development of the modern law of blockade. Another step further is considering a blockade unlawful in the situation in which a belligerent willingly chooses not to address the violation to which the blockade is attributing or addresses it but fails to take sufficient steps. If no other means are sought to 'justify' the blockade, it could thereby become an unlawful method of war. Such a view appears to be taken in the recently drafted Manual for Air and Missile warfare (AMW) ${ }^{88}$ in which the belligerent is given a choice to allow foodstuff through the aerial blockade or alternatively to lift the blockade. ${ }^{89}$ The difficulty will obviously be that it will be hard to determine whether or not the belligerent has taken sufficient steps.

\section{Conclusions}

In 1992 Schmitt posed the question: 'Should the humanitarian principle be the sole determinant of whether a blockade is legal?' 90 Today it may not be the sole determinant but it cannot be ignored that the humanitarian aspects play a more and more important part in the question of whether a belligerent naval blockade is lawful or not. It seems that there is hardly any room for a more restrictive and legalistic approach based solely on the traditional law of blockade. The conclusion that must be drawn from the public reactions and the different reports that have been published so far on the flotilla incident is that the scope of the contemporary laws of blockade is still not settled. Views on what renders a blockade unlawful rely both on the more restrictive traditional perspective and modern perspective. Seen through

\footnotetext{
87 Turkel report, para. 97.

88 This Manual is available at: http://www.ihlresearch.org/amw/.

89 AMW, rule 157, commentary, para. 3.

90 Schmitt (1992), p. 65.
} 
the eyes of the public spectators who may have only have brief knowledge on how the laws of blockade are meant to work, the humanitarian perspective on the laws of war may very well outweigh the traditional approach. A right to humanitarian assistance during blockade operations may be an already generally accepted concept, but discussion remains whether the next step-to accept that not fulfilling provisions of humanitarian law in general may render a blockade unlawful—could at this stage of the development of the modern law of blockade be a step too far. There is no disagreement that the unlawfulness of a blockade can arise when there is a breach of a principle of the laws of war, such as proportionality. The opposing views on the Israeli military actions against the Mavi Marmara demonstrate however the difficulty in assessing whether such an action is proportionate or not.

The practice of the Israeli blockade operations represent the first time that the provisions of SRM on blockade have been put to a practical test in a classical belligerent blockade. And it is safe to say that they have passed. This has strengthened the SRM's position as authoritative guidelines of the law of blockade and places a new puzzle-piece in the development the laws of naval warfare to contemporary standards. Many unplaced puzzle pieces with regard to the development of the law of blockade remain. This article has, for instance, not delved into many other equally interesting issues with respect to the laws of blockade that also emerge from the present use of the blockade by Israel, such as the relationship between the law of blockade and the international law of the sea, and the freedom of the high seas in particular, or the handling of detainees during blockade operations.

On 26 December 2010 the Mavi Marmara returned to its Turkish home port ${ }^{91}$ which closed, for now, an episode that some will remember as a violation of international law and others as a legal intervention upon a breach of blockade.

Open Access This article is distributed under the terms of the Creative Commons Attribution Noncommercial License which permits any noncommercial use, distribution, and reproduction in any medium, provided the original author(s) and source are credited.

\section{References}

Ashley Roach J (2000) The law of naval warfare at the turn of two centuries. AJIL 94:64, 64-77

Baer GW (1993) The U.S. Navy 1890-1990. One hundred years of sea power. Stanford University Press, California, pp 320-324 (on Korea)

Barnett RW (2005) Technology and naval blockade. Past impact and future prospect. Nav War Coll Rev 58(3):87-98

Bentwich N (1911) The declaration of London. Sweet \& Maxwell Limited, London, p 50

Blank LR (2009) The application of IHL in the Goldstone Report: a critical commentary. Yearb Int Humanit Law 12:347-402

Boczek BA (1989) Law of warfare at sea and neutrality: lessons from the Gulf War. Ocean Dev Int Law 20:239-271

Colombos CJ (1962) The international law of the sea, 5th edn. Longmans, London, p 687

Dalton JG (2006) A comparison between the San Remo manual and the U.S. Navy Commanders' Handbook. Israel Yearb Hum Rights 36:71-88

\footnotetext{
91 http://www.guardian.co.uk/world/2010/dec/26/gaza-flotilla-ship-returns-turkey.
} 
Darcy S, Reynolds J (2010) An enduring occupation: the status of the Gaza strip from the perspective of international humanitarian law. J Confl Secur Law 15(2):211-243

Dershowitz A (2010) Israel obeyed international law: legally, the Gaza flotilla conflict is an open-andshut case. In: New York Daily News, 2 June 2010. http://www.nydailynews.com/opinions/ 2010/06/02/2010-06-02_israel_obeyed_international_law_legally_the_gaza_flotilla_conflict_is_an_ openand.html\#ixzz1D1OumLAs

Dinstein Y (2004) The conduct of hostilities under the law of international armed conflict. Cambridge University Press, London, pp 137-138

Doswald-Beck L (1995a) San Remo Manual on International law applicable to armed conflicts at sea, section 93-104

Doswald-Beck L (1995b) The San Remo Manual on international law applicable to armed conflicts at sea. AJIL 89:192-208

Doswald-Beck L (1995c) San Remo Manual on international law applicable to armed conflict at sea. In: International Review of the Red Cross, no. 309, November-December 1995, pp 583-594

Ducheine P, Pouw E (2009) Operation change of direction: a short survey of the legal basis and the applicable legal regimes. In: de Weger MJ, Osinga FPB, Kirkels HFM (eds) NL annual review of military studies_complex operations: studies on Lebanon (2006) and Afghanistan (2006-present), Breda, pp 51-97

Fielding LE (1993) Maritime interception: centrepiece of economic sanctions in the new world order. Louisiana Law Rev 53:1191-1241

Fink MD (2008) De maritieme taakgroep UNIFIL te Libanon. Militair Rechtelijk Tijdschrift 101(4):103-112

Fink MD (2010) Het blokkaderecht. Nederlands Juristenblad 85:2032-2034

Fraunces MG (1992) The international law of blockade: new guiding principles in contemporary state practice. Yale Law J 101:893-918

Garner JW (1927) Prize law during the World War. A study of jurisprudence of the prize courts, 1914-1924

Geiss R (2005) Humanitarian safeguards in economic sanctions regimes: a call for automatic suspension clauses, periodic monitoring, and follow-up assessment of long-term effects. Harvard Hum Rights J 18:167-199

Goldie LFE (1991) Maritime war zones and exclusion zones. In: International law studies, vol 64. Naval War College Press, Newport, pp 156-204

Green LE (2000) The contemporary law of armed conflict, 2nd edn. Manchester University Press, Manchester

Guilfoyle D (2010) Gaza fleet raid raises questions over legality of Israel's blockade. In: Times Online, 1 June 2010. http://business.timesonline.co.uk/tol/business/law/article7142055.ece

Guilfoyle D (2011) The Mavi Marmara incident and blockade in armed conflict. Draft paper 2011. http://www.ucl.ac.uk/laws/staff/docs/staffseminars

Heintschel von Heinegg W (1992) Commentary no 10. In: Heintschel von Heinegg W (ed) Methods and means of combat in naval warfare. Report and commentaries of the round-table of experts on international humanitarian law applicable to armed conflict at sea (Bochumer Schriften no. 8, Bochum), pp 105-106

Heintschel von Heinegg W (2006) How to update the San Remo Manual on the international law applicable to armed conflict at sea. In: Israel yearbook on human rights, pp 119-148

Henckaerts J-M, Doswald-Beck L (2005) Customary international law, vol 1. Cambridge University Press, Cambridge, pp 188-189

Jones TJ (1983) The international law of maritime blockade-a measure of naval economic interdiction. Howard Law J 26:759-780

Kershner I (2010) Israel reject international raid inquiry, envoy insists. In: International Herald Tribune, 7 June 2010, p 1, 5

Lambert AD (2006) The Crimean War blockade 1854-1856. In: Elleman BA, Paine SCM (eds) Naval blockades and seapower: strategies and counter-strategies, 1805-2005, pp 46-60

Massey S, Baker B (2009) Comoros: external involvement in a small island state. Chatham House programme paper AFP 2009/1 (July 2009). http://www.chathamhouse.org.uk/files/14527_ 0709comorospp.pdf

Michaelsen C (2003) Maritime exclusion zones in time of armed conflict at sea: legal controversies still unresolved. J Confl Secur Law 8(2):363-390 
Moore EF (1855-1857) Reports of cases heard and determined by the Judicial Committee and the Lords Her Majesty’s most honourable Privy Council, vol X, London, pp 37-69

Politakis GP (1994) UN-mandated naval operations and the notion of pacific blockade: comments on some recent developments. Afr J Int Comp Law 6:173-208

Politakis GP (1998) Modern aspects of the laws of naval warfare and maritime neutrality. Columbia University Press, Geneva, pp 35-165

Provost R (1992) Starvation as a weapon. Legal implications of the United Nations food blockade against Iraq and Kuwait. Colombia J Transnatl Law 30:577-640

Robertson HB (1991) Specific means and methods of application of force. Duke J Comp Int Law (1):1-23

Ronzitti N (1988) The Crisis of the traditional law regulating international armed conflicts at sea and the need for its revision. In: Ronzitti N (ed) The law of naval warfare 1

Rosensweig L (1995) United Nations Sanctions: creating a more effective tool for the enforcement of international law. Austrian J Public Int Law 48:161-195

Sandoz Y, Swinarski C, Zimmermann B (eds) (1987) Commentary on the additional protocols of 8 June 1977 to the Geneva Conventions of 12 August 1949, no. 2093-2096. Martinus Nijhoff Publishers, Geneva

Schmitt MN (1992) Aerial blockades in historical, legal and practical perspective. USAFA J Legal Stud 21(2):21-86

Schmitt MN (2008) “Change Direction” 2006: Israeli operations in Lebanon and the international law of self-defense. In: Carsten MD (ed) International law studies, vol 83. Naval War College, Newport, Rhode Island, pp 265-301

Sklaire MR (1990-1991) The Security Council blockade of Iraq: conflicting obligations under the United Nations Charter and the fourth Geneva Convention. Am Univ J Int Law Policy 6:608-636

Smith HA (1950) The law and custom of the sea, 2nd edn. Stevens \& Sons, London, p 112

Sterio M (2010) The Gaza Strip: Israel, its foreign policy and the goldstone report. Research paper 10-199, Cleveland-Marshall College of Law, October 2010, pp 6-7. http://ssrn.com/ abstract $=1699766$

Thomas AR, Duncan JC (1999) Annotated supplement to the commander's handbook on the law of naval operations. International law studies, nr. 73. (Naval War College)

Tucker RW (1955) The Law of war and neutrality at sea, pp 287-292

van Bylandt DL (1880) Het blokkade-recht. T.C.B. ten Hagen, Leiden, p 116

van Hegelsom GJF (1992) Introductory report. Method and means of combat in naval warfare. In: Heintschel von Heinegg W (ed) Bochumer schriften zur Friedenssicherung und zum Volkerrecht, vol 8, pp 1-60

Verzijl JW (1917) Het prijsrecht tegenover neutralen in den Wereldoorlog van 1914 en volgenden jaren, pp 186-223

Vreeken R (2010) Is de Blokkade illegaal? Dan de entering ook. In: Volkskrant, 2 June 2010. http://www.volkskrant.nl/vk/nl/2686/Binnenland/article/detail/982976/2010/06/02/Is-de-blokkadeillegaal-Dan-de-entering-ook.dhtml

Weingärtner D (2007) Das UNIFIL-mandat der Bundeswehr-politische und rechtliche Aspekte. Humanitares Volkerrecht-Informationschriften 20(2):116-120

Wynkoop TA (1995) The use of force against third party neutrals to enforce economic sanctions against a belligerent. Nav Law Rev XLII:91-119 